\title{
Analisis Nilai Kejujuran dalam Permainan Tatarucingan
}

\author{
PUPUNG RAHAYU NOVIATI, SENDI FAUZI GIWANGSA \\ 1)Prodi Pendidikan Guru Sekolah Dasar, Sekolah Tinggi Keguruan dan IImu Pendidikan, Sebelas April \\ Sumedang, 2) Prodi Pendidikan Guru Sekolah Dasar, Universitas Pendidikan Indonesia \\ Email: 1)noviati.rahayu@yahoo.com, ${ }^{2)}$ sendifauzigiwangsa@gmail.com
}

\section{DOI: https://doi.org/10.29313/ga.v3i1.4830}

\begin{abstract}
The purpose of this study is to analyze the play of tatarucingan, both related to the form of tatarucingan games, how to play the game of tatarucingan, the values contained in the game of tatarucingan and the implementation of honesty values in basic education. The method used in this study uses descriptive analytical methods. The result of this study is that tatarucingan game is an existing game that has been played by two or more people both by women and men. The value of honesty is in the activity when playing tatarucingan games.
\end{abstract}

Keywords: Honesty Value, Tatarucingan Game.

\begin{abstract}
Abstrak
Tujuan penelitian ini untuk menganalisis permainan tatarucingan, baik yang berkaitan dengan bentuk permainan tatarucingan, cara memainkan permainan tatarucingan, nilai-nilai yang terkandung dalam permainan tatarucingan serta implementasi nilai kejujuran dalam pendidikan dasar. Metode yang digunakan dalam penelitian ini menggunakan metode deskriptif analitik. Hasil dari penelitian ini adalah permainan tatarucingan merupakan permainan yang sudah ada sejak dulu yang dimainkan oleh dua orang atau lebih baik oleh perempuan maupun laki-laki. Nilai kejujuran terdapat dalam aktivitas ketika memainkan permainan tatarucingan.
\end{abstract}

Kata Kunci: Nilai Kejujuran, Permainan Tatarucingan. 


\section{Pendahuluan}

Kemajuan teknologi yang semakin pesat ternyata juga mempengaruhi aktivitas bermain anak. Sekarang, anak-anak lebih sering bermain permainan digital seperti video games, Playstation (PS), dan games online (Haerani: 2013). Kesan modern ternyata tidak selamanya berdampak positif. Fenomena yang terjadi Akhir-akhir ini, permainan digital berdampak buruk terhadap anak (Haerani: 2013). Salah satu contoh dampak buruk dari game digital (Haerani: 2013) diantaranya kecanduan yang sudah melewati ambang batas, sehingga anak-anak menghabiskan waktunya berjam-jam tanpa peduli terhadap diri-sendiri dan lingkungannya. Dengan bermain games anak bisa menjadi lupa makan, beribadah, mengerjakan tugas sekolah, hingga rela bolos sekolah demi bermain game digital.

Di balik banyaknya dampak negatif yang telah ditimbulkan oleh permainan digital yang memiliki kesan modern ini, sebenarnya bangsa Indonesia memiliki banyak permainan tradisional. Permainan-permainan tradisional ada di Indonesia tidak hanya memberikan kesenagan kepada anak naamun juga kaya akan nilai-nilai yang dapat mendukung terhadap tumbuh kembang anak (Haerani: 2013).

Permainan tradisional anak-anak adalah salah satu genre atau bentuk folklore yang berupa permainan anak-anak, yang beredar secara lisan diantara anggota kolektif tertentu, berbentuk tradisional dan diwarisi turun temurun serta banyak mempunyai variasi (Danandjaja: 1987). Oleh karena termasuk folklore, maka sifat atau ciri dari permainan tradisional anak sudah tua usianya, tidak diketahui asal-usulnya, siapa penciptanya dan dari mana asalnya dan biasanya disebarkan dari mulut ke mulut dan kadangkadang mengalami perubahan nama atau bentuk meskipun dasarnya sama (Danandjaja: 1987). Jika dilihat dari akar katanya, permainan tradisional tidak lain adalah kegiatan yang diatur oleh suatu peraturan permainan yang merupakan pewarisan dari generasi terdahulu yang dilakukan manusia (anak-anak) dengan tujuan mendapat kegembiraan (Danandjaja: 1987).
Permainan tradisional banyak dimainakan oleh anak-anak karena mudah untuk memaiknanya karena alat-alat permainan banyak menggunakan benda-benda yang ada di lingkungan. Selain menyenangkan bagi anak, dalam permainan tradisional juga terdapat nilainilai yang terkandung di dalamnya. Seperti hasil penelitian dari Ariani, (1998:2) yang menyebutkan bahwa ada beberapa nilai yang terkandung dalam permainan tradisional yang dapat ditanamkan dalam diri anak antara lain rasa senang, adanya rasa bebas, rasa berteman, rasa demokrasi, penuh tanggung jawab, rasa patuh dan rasa saling membantu yang kesemuanya merupakan nilai-nilai yang sangat baik dan berguna dalam kehidupan bermasyarakat. Hal itu sejalan dengan hasil penelitian Kurniati (2011:13) yang menunjukkan bahwa permainan anak tradisional dapat mestimulasi anak dalam mengembangkan kerjasama, membantu anak menyesuaikan diri, saling berinteraksi secara positif, dapat mengkondisikan anak dalam mengontrol diri, mengembangkan sikap empati terhadap teman, menaati aturan, serta menghargai orang lain.

Berbagai nilai luhur yang terkandung di dalam permainan anak tradisional tersebut menggambarkan bahwa permainan anak tradisional dapat digunakan sebagai media yang tepat untuk membentuk kepribadian anak, oleh sebab itu keberadaan permainan tradisional hendaknya tetap dilestarikan (Ariani, 1998:3). Salah satu permainan tradisional yang sering dimainkan oleh anak-anak yaitu permainan Tatarucingan. Permainan Tatarucingan sekarang ini sudah jarang dimainkan oleh anak-anak karena tergeser oleh banyaknya permainan digital seperti game online ataupun permainan yang terdapat pada handphone (Kurniati, 2013)

Seperti dikemukakan di atas bahwasanya permainan tradisional banyak mengandung nilainilai yang baik bagi dan berguna dalam kehidupan masyarakat. Terlebih permainan merupakan

dunia anak-anak. Usia anak merupakan usia yang tepat untuk menanamkan nilai-nilai pendidikan. nilai-nilai pendidikan akan menjadi landasan bagi anak dalam berperilaku dikemudian hari. Oleh karena itu, nilai-nilai pendidikan 
seyogyanya ditanamkan sedini mungkin pada anak. Permainan tradisional, khususnya Tatarucingan bisa dijadikan alternatif sebagai salah satu cara dalam menanamkan nilai-nilai pendidikan.

Berdasarkan hasil-hasil penelitian terdahulu, masih belum ditemui penelitian yang menggali nilai-nilai pendidikan dalam permainan Tatarucingan. Berdasarkan hal tersebut, penulis tertarik untuk membuat artikel dengan tema "analisis nilai kejujuran dalam permainan Tatarucingan pada Siswa SD".

\section{Metodologi Penelitian}

Artikel ini menggunakan metode kepustakaan dan metode lapangan. Metode kepustakaan dengan cara membaca dan mempelajari materi yang relevan dengan materi ruang lingkup permasalahan. Sementara kajian lapangan untuk memperkuat pemahaman konsep, bentuk serta aktivitas dari permainan Tatarucingan dengan menganalisis berbagai buku dan artikel-artikel dalam jurnal. Adapun teknik pengumpulan data dalam artikel ini yaitu sebagai berikut:

\begin{tabular}{|c|c|c|}
\hline Teknik & Sumber & Data/Informasi \\
\hline Wawancara & $\begin{array}{l}\text { 1. Bapak Engkong } \\
\text { (sesepuh dan ahli seni } \\
\text { di Kabupaten } \\
\text { Sumedang) } \\
\text { 2. Bapak Rony Hidayat } \\
\text { (ahli seni di Kabupaten } \\
\text { Sumedang) }\end{array}$ & $\begin{array}{l}\text { 1. Pengertian permainan } \\
\text { Tatarucingan } \\
\text { 2. Aturan permainan } \\
\text { Tatarucingan }\end{array}$ \\
\hline Observasi & $\begin{array}{ll}\text { 1. } & \text { Permainan } \\
& \text { Tatarucingan oleh } \\
\text { siswa SDN Sukalerang } & \\
\text { II } \\
\text { 2. } & \text { Permainan } \\
& \text { Tatarucingan } \\
& \text { anak-anak di Desa } \\
\text { Galudra } & \text { Dusun } \\
\text { Gajahdepa } & \end{array}$ & $\begin{array}{l}\text { 1. Cara memainkan } \\
\text { permainan } \\
\text { Tatarucingan }\end{array}$ \\
\hline
\end{tabular}

Kajian lapangan dilaksanakan di Desa Serang dan Galudra Kecamatan Cimalaka Kabupaten Sumedang pada tahun 2019. Untuk memperoleh data-data tersebut dilakukan teknik wawancara serta observasi. Wawancara dilakukan terhadap 2 orang yaitu bapak Engkong (65 Tahun) selaku sesepuh dan ahli seni di Kabupaten Sumedang, serta bapak Rony Hidayat (37 Tahun) selaku ahli seni dan dosen seni di PGSD STKIP Sebelas April. Sedangkan Observasi dilakukan dua kali yaitu pertama pada tanggal 3 April dengan mengobservasi permainan Tatarucingan yang dimainkan oleh anak-anak di SDN Sukalerang II. Sedangkan Observasi ke dua dilaksanakan pada tanggal 13 April dengan mengobservasi permainan Tatarucingan yang dimainkan oleh anak-anak di lingkungan desa Galudra Kecamatan Cimalaka. Temuan penelitian diperoleh dengan memadukan hasil dari studi kepustakaan dan studi lapangan.

\section{Hasil dan Pembahasan}

Tatarucingan adalah bentuk permainan tradisioal dimana para pemain saling menebak pertanyaan. Tatarucingan bisa dilakukan oleh perempuan maupun laki-laki. Permainan ini populer tahun 1990an sampai sekarang.

Adapaun langkah-langkah permainan Tatarucingan yaitu sebagai berikut:

1) Nama Permainan : Tatarucingan 
2) Jumlah Pemain : 2 orang atau lebih

3) Alat dan Bahan : -

4) Cara Bermain

a) Permainan dimulai dengan membuat 2 team jika pemain lebih dari 3 orang, jika pemain hanya 2 orang tidak perlu membuat team.

b) Setelah dibentuk 2 team, kedua tema melakukan suit untuk menentukan team mana yang pertama kali memberikan tarucing (tebakan).

c) Team yang menang terlebih dahulu memberikan tebakan yang harus dijawab team yang kalah.

d) Selanjutnya team yang kalah giliran memberikan tebakan pada team yang menang, begitu seterusnya.

e) Team yang menang adalah team yang paling banyak menjawab tebakan yang benar.

\section{Pembahasan}

Nilai adalah suatu pengertian yang mengandung sifat baik atau buruk untuk memberikan penghargaan terhadap barang atau benda (Danandjaya, 1987). Manusia meyakini sesuatu bernilai,karena ia merasa memerlukannya atau menghargainya. Dengan akal dan budinya manusia menilai dunia dan alam sekitarnya untuk memperoleh kepuasan diri baik dalam arti memperoleh apa yang diperlukannya, apa yang menguntungkannya, atau apa yang menimbulkan kepuasan batinnya (Danandjaya, 1987). Manusia sebagai mahluk budaya, memiliki aspek kognitif untuk mencipta; aspek emosi untuk mengolah rasa, aspek perilaku untuk berkehendak; aspek spiritual untuk berhubungan dengan transendental. Dan dengan kesemuanya itu, manusia mampu berkarya dengan menghasilkan bentuk-bentuk budaya di dalam masyarakat, yang membuktikan keberadaan manusia dalam kebersamaan dan semua bentuk budaya itu mengandung nilai.

Secara garis besar nilai yang bersifat baik (virtues) dibagi dalam dua kelompok yaitu nilainilai nurani (values of being) dan nilai-nilai memberi (values of giving) (Linda, 1995). Nilai- nilai nurani adalah nilai yang ada dalam diri manusia kemudian berkembang menjadi perilaku serta cara kita memperlakukan orang lain. Yang termasuk dalam nilai-nilai nurani adalah kejujuran, keberanian, cinta damai, keandalan diri, potensi, disiplin, tahu batas, kemurnian, dan kesesuaian. Nilai-nilai memberi adalah nilai yang perlu dipraktikkan atau diberikan yang kemudian akan diterima sebanyak yang diberikan. Yang termasuk pada kelompok nilai-nilai memberi adalah setia, dapat dipercaya, hormat, cinta, kasih sayang, peka, tidak egois, baik hati, ramah, adil, dan murah hati (Linda, 1995).

Berdasarkan deskripsi di atas, bahwasanya nilai kejujuran termasuk dalam bagian nilai nurani yang ada dalam diri manusia yang kemudian akan berkembang menjadi perilaku dalam memperlakukan orang lain.

Berdasarkan analisis dari pengertian, bentuk serta aktivitas dalam permainan Tatarucingan baik dari studi kepustakaan dan studi lapangan, diasumsikan bahwa nilai kejujuran terdapat dalam aktivitas dalam permainan Tatarucingan yaitu pada bagian dimana pihak lawan menebak jawaban tebakan, jawaban harus konsisten apakah benar atau salah. Jangan pihak lawan menjawab benar, tetapi menjadi "salah" karena pihak pemberi pertanyaan ingin menang.

$\mathrm{Hal}$ ini di perkuat oleh hasil penelitian dari Misbach (2006) yang menyatakan bahwa permainan tradisional (congklak) dapat menstimulasi berbabagai aspek perkembangan anak yang salah satunya yaitu aspek nilai. Selain itu Nurjaman (2009) mengatakan bahwa permainan congklak dapat mengembangkan kejujuran, toleransi dan saling menghargai.

1. Penanaman Nilai Kejujuran dalam Pendidikan Dasar

Penanaman nilai kejujuran dalam pendidikan dasar menurut diantaranya dapat melalui berbagai cara diantaranya yaitu sebagai berikut.

a. Melalui keteladanan baik dari guru maupun orang tua. Diharapkan dengan keteladanan nilai-nilai kejujuran dapat dicontoh 
oleh anak, sehingga nilai kejujuran sudah dikenalkan sejak anak usia dini.

b. Melalui pembiasaan di sekolah melalui membiasakan berkata jujur, kalau berjanji ditepati dan tidak mencontek

c. Melalui pemasangan slogan atau poster di sekolah.

d. Melalui penyedian tempat temuan barang hilang.

Hal itu sejalan dengan hasil penelitian dari Hulaini (2017) yang mengatakan bahwa penanaman nilai kejujuran dapat melalui keteladanan, pembiasaan, serta pengintegrasian dalam beberapa mata pelajaran. Sedangkan Yuliani (2013) mengatakan bahwa salah satu bentuk penananman nilai kejujuran yaitu dengan diadakannya kantin kejujuran, dimana siswa dilatih untuk jujur dalam mengambil barang dan membayarnya dan mengambil uang kembalian secara mandiri ke tempat yang sudah disediakan.

2. Nilai Prediktif (fungsi Tatarucingan dalam pendidikan dasar)

Permainan Tatarucingan dapat dikembangkan menjadi sebuah media pembelajaran untuk menanamkan niainilai kejujuran. Dengan memainkan permainan Tatarucingan siswa akan dibiasakan untuk selalu berperilaku jujur meskipun dalam situasi bermain. Selain itu dengan permainan Tatarucingan juga dapat melestarikan permainan tradisional yang sekarang ini sudah mulai tersisihkan dengan banyaknya permainan digital.

Selain itu permaianan Tatarucingan juga dapat dikembangkan untuk menjadi sebuah model pembelajaaran dengan mengikuti langkah-langkah permainan Tatarucingan yang akan digunakan untuk menanamkan berbagai karakter serta pengetahuan dan keterampilan bagi anak-anak sekolah dasar yang nantinya dapat disesuaikan dengan berbagai materi dalam mata pelajaran-mata pelajaran di sekolah dasar.

\section{Kesimpulan}

Berdasarkan pembahasan di atas maka dapat disimpulkan sebagai berikut:

Permainan Tatarucingan merupakan permainan yang sudah ada sejak dulu yang dimainkan oleh dua orang atau lebih baik oleh perempuan maupun laki-laki. Nilai kejujuran terdapat dalam aktivitas ketika memainkan permainan Tatarucingan.

\section{Daftar Pustaka}

Achroni, S. (2012). Mengoptimalkan Tumbuh Kembang Anak Melalui Permainan Tradisional. Jogjakarta: Javalivera

Ariani, C. (1998). Pembinaan Nilai Budaya Melalui Permainan Rakyat Daerah Istimewa Yogyakarta. Yogyakarta: Depdikbud, Dirjen Kebudayaan, Direktorat Sejarah dan Nilai Tradisional.

Danandjaja, J. (1986). Folklore Indonesia: Ilmu gossip, dongeng, dan lain-lain. Jakarta: PT.Grafitipers.

Danandjaya, J. (1987). Floklore Indonesia. Jakarta : Gramedia.

Haerani, N. (2013). Membangun Karakter Anak Melalui Permainan Anak Tradisional. Jurnal Pendidikan Karakter, Tahun III, No 1, Februari 2013

Hulaini, N. (2017). Implementasi Pendidikan Karakter Jujur dalam MembentukKepribadian Siswa Kelas VII di SMP Negeri 19 Palembang. Skripsi: Tidak dipublikasikan.

Kurniati, E. (2011). Program Bimbingan untuk Mengembangkan Keterampilan Sosial Anak Melalui Permainan Tradisional. Surakarta: Skripsi Universitas Muhammadiyah Surakarta. Tidak diterbitkan.

Linda, N. (1995). Teaching Your Children Values. New York: Simon Sand Chuster 
Misbach, I. 2006. Peran Permainan Tradisional yang Bermuatan Edukatif dalam Menyumbang Pembentukan Karakter dan Identitas Bangsa. Laporan Penelitian. Bandung: Universitas Pendidikan Indonesia. Tidak diterbitkan.

Nurjaman, D. (2009). Seri Olahraga Permainan Tradisional. Bandung: CV. Mitra Sasana.

Putra, dkk. (2017). Peningkatan Kapasitas Working Memory melalui permainan congklak pada Siswa Sekolah Dasar. Jurnal Psikologi Volume 44, Nomor 1, 2017:DOl: 10.22146/jpsi.21984

Yuliani. (2013). Kajian Kantin Jujur dalam Rangka Peningkatan Pendidikan Karakter Di Tingkat Sekolah Dasar Untuk Mewujudkan Siswa Yang Kreatif (Studi Kasus DI SDN Panggungrejo 04 Kapenjen). Jurnal Pemikiran dan Pengembangan SD, Jilid 1 Nomor 2, September 2013 